N. Papić, M. Marcikić*

\title{
VJEŠTAČENJE NESREĆA UZROKOVANIH STRUJNIM UDAROM
}

UDK 614.825:340.62

PRIMLJENO: 28.12 .2017$.

PRIHVAĆENO: 21.3.2018.

SAŽETAK: U radu je na primjeru realnog slučaja nesreće prikazan rad vještaka za elektrotehniku prilikom utvrđivanja uzroka strujnog udara. Prikazane su okolnosti nesreće i postupak vještačenja materijala izuzetog s mjesta događaja nesreće. Osim toga, opisane su mjere sigurnosti koje treba poštovati pri radu na mjestu događaja nesreća uzrokovanih strujnim udarom.

Autori daju podatke o učincima električne struje na ljudski organizam u slučaju strujnog udara, što je područje rada sudsko-medicinskog vještaka.

Vještačenje uzroka strujnog udara je kombinirano vještačenje vještaka za elektrotehniku i sudsko-medicinskog vještaka pa je na kraju prikazano jedno takvo vještačenje na sudskoj raspravi.

Ključne riječi: nesreće, strujni udar, elektrotehničko vještačenje, sudsko-medicinsko vještačenje, sudska rasprava

\section{UVOD}

Električni udari (strujni udari) nisu tako česti uzroci nesreća i smrtnog stradavanja, ali se pojavljuju i kao takvi su predmet istraživanja kako vještaka za elektrotehnička vještačenja, tako i sudsko-medicinskog vještaka (Papić, 2017.). Vještak za elektrotehniku, pregledom mjesta događaja nesreće, utvrđuje okolnosti i pronalazi tragove, te otkriva kvar na električnoj instalaciji ili uređaju koji je mogao dovesti do strujnog udara. Doktor, pregledom osobe koja je doživjela strujni udar, zaključuje na temelju tragova na tijelu i dodatnih pregleda o uzroku ozljeda, odnosno u slučaju smrtnog stradavanja na temelju obdukcije, daje svoj nalaz i mišljenje o uzroku smrti.

*Nenad Papić, dipl. ing. el., (npapic@mup.hr), samostalni vještak za tehnička vještačenja, MUP RH, Centar za forenzična ispitivanja, istraživanja i vještačenja "Ivan Vučetić", Ilica 335, 10000 Zagreb, prof. dr. sc. Mladen Marcikić, dr. med., (mladen.marcikic@os.t-com.hr), stalni sudski vještak sudske medicine, Klinički bolnički centar Osijek, Klinički zavod za patologiju i sudsku medicinu, 31000 Osijek
Vještačenje uzroka strujnih udara provodi se pregledom i ispitivanjem električne instalacije i električnih uređaja u objektu od vještaka za elektrotehnička vještačenja. Također se vještače i izuzeti električni uređaji (aparati) koji se dostavljaju na vještačenje zbog sumnje da su radi kvara mogli izazvati strujni udar. $U$ oba slučaja radi se o kombiniranom vještačenju za koje je pored elektrotehničkog vještačenja potrebno i sudsko-medicinsko vještačenje u vezi s ozljedom i uzrokom ozljeđivanja, odnosno uzrokom smrti.

Elektrotehničkim vještačenjem utvrđuje se je li do strujnog udara došlo zbog tehničkog kvara ili neispravnosti na električnoj instalaciji ili električnom uređaju, što je najčešće posljedica nemara, a vrlo rijetko hotimičnog djelovanja druge osobe.

Do strujnog udara može doći direktnim (izravnim) dodirom s dijelovima pod naponom ili indirektnim (neizravnim) dodirom dijelova 
pod naponom kao posljedica kvara na izolaciji električnih uređaja. Također do strujnog udara može doći približavanjem dijelovima pod visokim naponom.

Statistički podaci (Srb, 1991.) pokazuju da je oko $5 \%$ nesreća izazvanih udarom električne struje smrtonosno, a od ukupnog broja nesreća $85 \%$ izazvano je naponom do $1000 \mathrm{~V}$, a preostalih $15 \%$ naponom iznad $1000 \mathrm{~V}$. Od ukupnog broja nesreća od elektrokucije koje su uzrok smrti, 80-85 \% stradavaju muškarci, a 15$20 \%$ nastradalih su žene, dok najviše stradavaju osobe starosti 25-34 godine. Nadalje, podaci pokazuju da kod napona od 1000 V, 3-4 \% nesreća završava smrću, a pri naponu preko $1000 \mathrm{~V}$ 12 \% nesreća završava smrću na temelju čega se može zaključiti da su nesreće na visokom naponu rjeđe, ali su oko 4 puta opasnije.

U članku je opisan jedan realni slučaj stradavanja zbog strujnog udara, koji je bio predmet zajedničkog rada vještaka za elektrotehniku i sudsko-medicinskog vještaka, a predmet je završen zajedničkim vještačenjem usmenim nalazom i mišljenjem vještaka na sudskoj raspravi.

\section{PRIPREMA ZA RAD I OSIGURANJE MJESTA RADA VJEŠTAKA ZA TEHNIČKA VJEŠTAČENJA}

\section{Utvrđivanje činjenica i priprema za rad}

Prije pregleda mjesta događaja utvrđuju se sve relevantne činjenice u vezi s nesretnim događajem:

- mjesto i vrijeme događaja, tko je nastradali i što je radio u vrijeme kad se dogodila nesreća,

- izjave očevidaca događaja o zapažanjima i opisu događaja,

- ako se radi o smrtnom stradavanju, trebaju se dobiti informacije o položaju tijela u trenutku pronalaska unesrećenog, te uvjetima okoline (suho ili mokro), vidljivim ozljedama na tijelu, te oštećenjima na odjeći i obući,
- od liječnika koji je pregledao nastradalog trebaju se dobiti informacije o ozljedama na tijelu, a nakon obdukcije o uzroku smrti,

- tražiti na uvid i pregledati tehničku dokumentaciju (sheme električne instalacije ili postrojenja),

- ako se radi o izvođenju radova na električnoj instalaciji, tražiti na uvid i pregledati radni nalog i interne pravilnike ili upute za rad,

- dobiti informacije kada i na koji način je isključeno napajanje objekta (ili postrojenja) električnom energijom,

- dobiti informacije je li došlo do isključenja napajanja proradom zaštite,

- dobiti informacije što je od električnih uređaja bilo u funkciji u trenutku događaja.

\section{Osiguranje mjesta rada}

Pravilnik o sigurnosti i zdravlju pri radu $s$ električnom energijom propisuje pet osnovnih pravila sigurnosti nazvanih „pet zlatnih pravila" za siguran rad u beznaponskom stanju koja čine zaštitne mjere za osiguranje mjesta rada:

1. isključiti i odvojiti od napona

2. osigurati od slučajnog uključenja

3. utvrditi beznaponsko stanje

4. uzemljiti i kratko spojiti

5. ograditi mjesto rada od dijelova pod naponom.

Prema navedenim pravilima na jednostavno napajanim strujnim krugovima niskog napona (razvodnim postrojenjima i električnim instalacijama), izuzev nadzemnih vodova, ne treba uzemljivati i kratko spajati vodiče, te za rad najčešće treba primijeniti samo tri prva pravila za osiguranje mjesta rada:

- isključivanje i odvajanje od napona

- sprečavanje ponovnog uklopa

- utvrđivanje beznaponskog stanja. 
Za osiguranje mjesta rada prije pregleda mjesta događaja zbog utvrđivanja uzroka strujnog udara treba učiniti sljedeće:

- Prije ulaska na mjesto događaja potrebno je utvrditi je li napajanje električnom energijom isključeno zbog sigurnosti ljudi prilikom kretanja i obavljanja pregleda mjesta događaja.

- Pregled priključka objekta na električnu mrežu i provjeru je li isti isključen $s$ napajanja treba izvoditi samo uz pomoć djelatnika Elektre ili električara zaduženog za održavanje električne instalacije u objektu.

- Provjerom je potrebno sigurno utvrditi da je objekt isključen s mrežnog napajanja te osigurati da za vrijeme rada u objektu ne dođe do ponovnog uključenja električne energije u objektu ili u jednom dijelu objekta.

- Kod pregleda visokonaponskih postrojenja treba raditi uz pomoć djelatnika Elektre ili radnika poduzeća zaduženih za održavanje postrojenja.

- Pregled postrojenja treba obavljati uz pomoć kvalificiranih zaposlenika koji dobro poznaju konkretno postrojenje.

\section{ELEKTROKUCIJA ILI UDAR ELEKTRIČNE STRUJE}

\section{Prolaz električne struje kroz ljudsko tijelo i granice opasnih napona}

Elektrokucija je svjesno ili nesvjesno izlaganje čovjeka djelovanju električne struje. Za djelovanje električne struje na čovjeka najvažnija je jakost električne struje (Tablica 1); (Srb, 1991.). Razlikuju se otpuštajuća struja, najveća struja pri kojoj se čovjek još može snagom svojih mišića odvojiti od dijelova pod naponom, fibrilacijska struja, ona jakost struje pri kojoj kod nekih ljudi može nastupiti smrt i nefibrilacijska struja, čijim djelovanjem ne može biti izazvana smrt (Srb, 1991.).
Tablica 1. Djelovanje električne struje u ovisnosti o jakosti struje

Table 1. Impact of electric power in relation to effective current

\begin{tabular}{|c|c|}
\hline Jakost struje & Djelovanje struje \\
\hline 10 do $16 \mathrm{~mA}$ & Otpuštajuća \\
\hline$<50 \mathrm{~mA}$ & Nefibrilacijska \\
\hline 50 do $100 \mathrm{~mA}$ & Opasna za život \\
\hline$>100 \mathrm{~mA}$ & Fibrilacijska \\
\hline
\end{tabular}

Električna struja opasna je za ljudsko tijelo kada prilikom dodira dijelova pod naponom kroz tijelo ili dio tijela teče električna struja i ljudsko tijelo postaje dio zatvorenog strujnog kruga. To se događa kada čovjek dođe u dodir: sa dva vodiča strujnog kruga između kojih vlada napon, sa jednim vodičem pod naponom i sa zemljom, s metalnim dijelom (kućištem) električnog uređaja koje je došlo pod napon zbog greške na izolaciji, te ako čovjek dođe u blizinu visokog napona tako da dođe do proboja izolacije (zraka) i preskoka napona u obliku električnog luka ili na neki drugi način.

Veličina struje koja prolazi kroz ljudsko tijelo određena je Ohmovim zakonom:

$$
I=\frac{U}{R}
$$

gdje su:

I - struja koja protječe kroz tijelo (A)

$U$ - napon dodira $(\mathrm{V})$

$\mathrm{R}$ - otpor ljudskog tijela $(\Omega)$.

U praksi se govori o otporu ljudskog tijela koji se sastoji od unutarnjeg otpora i otpora kože. Unutarnji otpor tijela iznosi 500 do $750 \Omega$, što ovisi o masi ljudskog tijela, a obično se uzima da je otpor ljudskog tijela $1300 \Omega$ kod $220 \mathrm{~V}$ i $50 \mathrm{~Hz}$.

Otpor ljudskog tijela ovisi o: vlažnosti (znojenju) kože, muskulaturi, trajanju djelovanja, visini napona, vrsti struje, frekvenciji, temperaturi tijela (kod fizičkog napora otpor je manji), duševnom stanju (u euforičnom stanju otpor je manji) i drugom. 
Za djelovanje struje na čovjeka važan je put struje kroz tijelo, a najopasniji put je kroz srce do čega dolazi kada struja prolazi putem: ruka-ruka i ruka-noga, tako da oko $90 \%$ smrtnih slučajeva nastaje pri dodiru dijelova pod naponom jednom rukom, dok je druga ruka ili noga bila dobro uzemljena.

Granice opasnih napona određene su propisima na temelju djelovanja struja različitih jakosti i prosječne impedancije ljudskog tijela (Mileusnić, 1999.).

Za normalne uvjete okoline i rada trajno dopušteni napon dodira je napon manji od $50 \mathrm{~V}$ za izmjeničnu struju i napon manji od $120 \mathrm{~V}$ za istosmjernu struju.

Za teže uvjete rada i okoline (vlaga i drugo) propisani su granični napon dodira od $25 \mathrm{~V}$ za izmjeničnu struju i $60 \mathrm{~V}$ za istosmjernu struju.

\section{Učinci električne struje na ljudski organizam}

Tjelesni dodir s električnim vodičima pod naponom može uzrokovati različite učinke (Dettmeyer et al., 2014.):

- električnu ozljedu stimulacijom mišića, živaca i srčanog vodljivog sustava,

- elektrotermičke ozljede zagrijavanjem tkiva prolaskom toka struje, karbonizaciju i metalizaciju tkiva,

- električni udar može uzrokovati i mehaničke ozljede zbog pada nakon udara.

Uobičajene su distinkcije na struje jako niskog napona, niskog, visokog i ekstra visokog napona. Struje u kućanstvu su 220 V, frekvencije $50 \mathrm{~Hz}$.

Bitni čimbenici koji utječu na nastanak električne ozljede su određeni Ohmovim zakonom $(\mathrm{I}=\mathrm{U} / \mathrm{R})$.

Drugi čimbenici električne ozljede su vrijeme trajanja kontakta, put struje kroz tijelo, osobito kad se srce nalazi u putu struje (put između kontaktnih mjesta od ruke do stopala ili od ruke do ruke). Također su važni dob, zdravlje osobe, faza srčane akcije u kojoj struja prođe kroz srce.
Važan čimbenik je i prag jakosti struje kad nastupa kontrakcija lokalnih mišića koji se više ne mogu nakon te razine jakosti aktivno otpustiti. Struje jakosti iznad 15 mA onemogućuju oslobađanje od kontakta s vodičem i kontinuirano prolaze kroz tijelo. Rizik nastupa aritmije rada srca je kod struja jakosti 50 mA, a kod jakosti od 80 $\mathrm{mA}$ dolazi do ventrikularne fibrilacije i gubitka svijesti.

Izmjenične struje u kućanstvima su napona $220 \mathrm{~V}$ i frekvencije $50 \mathrm{~Hz}$, što znači da struja pedeset puta u sekundi mijenja smjer, od plus do minus pola. Srce je osjetljivo na tu frekvenciju struje, jer kod nje nastupa fatalna aritmija. Istosmjerne struje su manje vulnerabilne od izmjeničnih. Visokofrekventne struje slabo prodiru u tijelo, ali imaju velik termički učinak na dodiru s konduktorima i elektrodama. Visokofrekventne struje 300 do $2000 \mathrm{kHz}$ primjenjuju se u kirurgiji.

Dijagnoza fatalnog udara električnom strujom je često dijagnoza temeljena na isključenju svih dugih čimbenika uzroka smrti i stoga zahtijeva zajedničko djelovanje tehničkog i medicinskog vještaka.

Fatalni električni udar ili elektrocutio se treba pažljivo ispitati i stoga mora uključiti tehničkog eksperta. Svi izvori električne struje, vodiči i uređaji moraju se ispitati, kao i mjesto samog događaja.

Medicinski se treba pronaći i utvrditi postojanje takozvanog električnog biljega, a to je električna opeklina. Električni biljezi, točke dodira s električnom strujom, mogu biti vrlo mali, nekarakteristični ili čak odsutni. Električne opekline će izostati u slučajevima dodira tijela sa širokim i vlažnim površinama.

Uobičajena električna opeklina ima na koži uleknuti središnji dio oko kojeg se nalaze uzdignuti rubovi, izgleda poput kratera. Mjehurići se nalaze u rubovima uzdignutog epidermisa. Histološki se nalazi deformacija bazalnog sloja, elongacija staničnih jezgara epidermisa. Metalne čestice od vodiča mogu biti zapečene u koži, pri čemu se radi o takozvanoj metalizaciji. Česti- 
ce metala mogu se detektirati histološkom analizom i spektrografski.

Tablica 2. Učinci jakosti i napona izmjenične električne struje na srce

Table 2. Impacts of effective current and voltage of alternating current on the heart

\begin{tabular}{||c|c|l||}
\hline $\begin{array}{c}\text { Jakost } \\
\text { struje }\end{array}$ & Napon & \multicolumn{1}{|c|}{ Djelovanje struje na srce } \\
\hline$<25 \mathrm{~mA}$ & Do $65 \mathrm{~V}$ & $\begin{array}{l}\text { Jako nizak napon: Nema oz- } \\
\text { ljeđujućeg djelovanja. }\end{array}$ \\
\hline$<25 \mathrm{~mA}$ & $100-130 \mathrm{~V}$ & $\begin{array}{l}\text { Nizak napon: Kratkotrajna } \\
\text { mišićna kontrakcija. }\end{array}$ \\
\hline $\begin{array}{c}25-80 \\
\mathrm{~mA} \text { (jakost } \\
\text { struje u } \\
\text { kućanstvu) }\end{array}$ & $110-380 \mathrm{~V}$ & $\begin{array}{l}\text { Nizak napon: Kratka asisto- } \\
\text { la i aritmija ili (reverzibilna) } \\
\text { ventrikularna fibrilacija po- } \\
\text { tencijalno opasna za život. }\end{array}$ \\
\hline $\begin{array}{c}80 \mathrm{~mA}- \\
8 \mathrm{~A}\end{array}$ & $110-380 \mathrm{~V}$ & $\begin{array}{l}\text { Nizak napon:Ventrikularna } \\
\text { fibrilacija (reverzibilna), po- } \\
\text { tencijalno opasna za život. }\end{array}$ \\
\hline$>8 \mathrm{~A}$ & $\begin{array}{c}2000- \\
\text { teo0, do }\end{array}$ & $\begin{array}{l}\text { Visoki napon: Elektrotermič- } \\
\text { ke opekline i akutna asistola. }\end{array}$ \\
\hline$>8 \mathrm{~A}$ & $>100000 \mathrm{~V}$ & $\begin{array}{l}\text { Visoki napon: Teške elektro- } \\
\text { termičke opekline (tempera- } \\
\left.\text { ture do 4000 }{ }^{\circ} \mathrm{C}\right), \text { karboniza- } \\
\text { cija, akutna asistola. Prijenos } \\
\text { toka struje moguć, čak i bez } \\
\text { kontakta s vodičem, električ- } \\
\text { ni luk. }\end{array}$ \\
\hline
\end{tabular}

Tablica 3. Učinci izmjenične električne struje

Table 3. Impacts of alternating current

\begin{tabular}{||c|c||}
\hline Jakost struje & Učinak električne struje \\
\hline$<0,5 \mathrm{~mA}$ & Perceptilno djelovanje tek jezikom. \\
\hline do $0,5 \mathrm{~mA}$ & Zamjetljivo bockanje, parastezije. \\
\hline od oko $5 \mathrm{~mA}$ & Mišićna ekscitacija. \\
\hline od oko $15 \mathrm{~mA}$ & $\begin{array}{c}\text { Mišićna kontrakcija, fleksijska kontrak- } \\
\text { cija, odvajanje od mjesta kontakta nije } \\
\text { više moguće. }\end{array}$ \\
\hline $25-50 \mathrm{~mA}$ & $\begin{array}{c}\text { Srčana aritmija, moguć gubitak svijesti } \\
\text { u slučaju duljeg kontakta. }\end{array}$ \\
\hline oko $50-80 \mathrm{~mA}$ & $\begin{array}{c}\text { Rizik nastanka akutne ventrikularne } \\
\text { fibrilacije. }\end{array}$ \\
\hline od $80 \mathrm{~mA}$ & $\begin{array}{c}\text { Kratko vrijeme kontakta je dovoljno } \\
\text { za nastanak ventrikularne fibrilacije. } \\
\text { Zatajenje disanja zbog paralize respi- } \\
\text { ratornih mišića. }\end{array}$ \\
\hline $3 \mathrm{~A}$ & $\begin{array}{c}\text { Elektrotermički učinak, karbonizacija } \\
\text { tkiva na mjestu kontakta. }\end{array}$ \\
\hline \hline
\end{tabular}

\section{REALNI SLUČAJ ELEKTRIČNOG UDARA KOD NISKOG NAPONA}

Prikazan je realni slučaj strujnog udara koji se dogodio prilikom korištenja električnog uređaja, pumpe za pretakanje mošta, a isti je bio predmet zajedničkog rada vještaka za tehnička vještačenja i doktora, vještaka za sudsku medicinu.

\section{Informacije iz dokumentacije očevida}

Uvidom u dostavljenu dokumentaciju očevida: zapisnik o očevidu, izvješće o kriminalističko-tehničkoj pretrazi mjesta događaja i fotografije s očevida, utvrđeno je sljedeće:

- Nastradali je, prilikom rada na električnoj pumpi za pretakanje mljevenog grožđa u električnu prešu, pao na tlo i preminuo.

- Mjesto događaja nesreće je pomoćna prostorija u produžetku obiteljske kuće, u kojoj se nalazila metalna cisterna za vino, plastična burad, dvije metalne preše za grožđe, muljača i električna pumpa za pretakanje tekućina (slika 1). Pod prostorije bio je betonski, mokar i na njemu se bili ostaci grožđa.

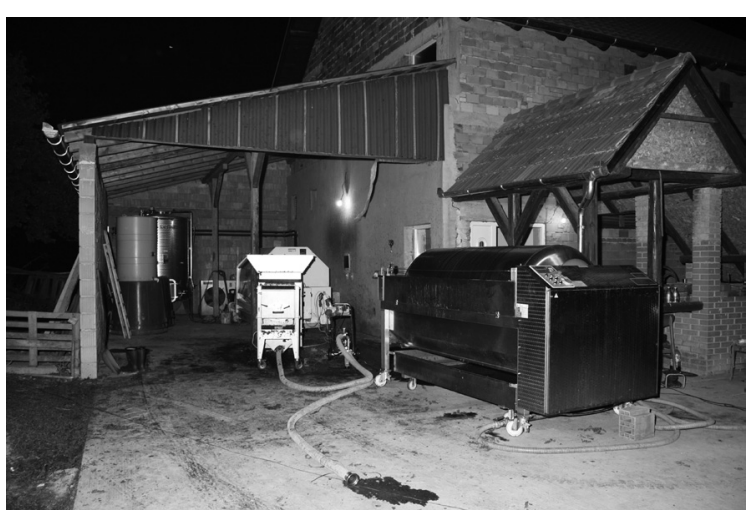

Slika 1. Mjesto događaja nesreće

Figure 1. Accident site

- Pumpa za pretakanje tekućine, označena je kao omot 1 i izuzeta s mjesta događaja zbog vještačenja, prikazana je na slici 2 na mjestu događaja nesreće. 


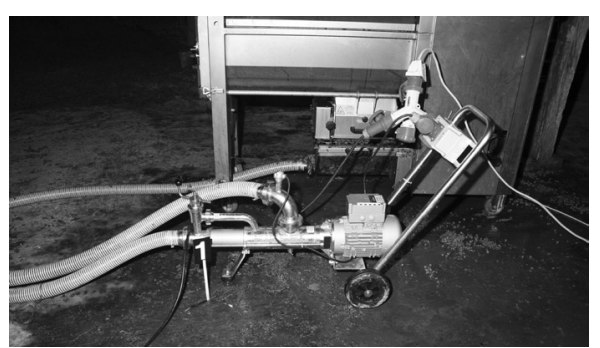

Slika 2. Pumpa za pretakanje mošta priključena na mjestu događaja nesreće

Figure 2. Grape must pump plugged in at the accident site

- Od pumpe za pretakanje tekućine pružao se električni kabel, koji je bio označen kao omot 2 i izuzet zbog vještačenja (slika 3).

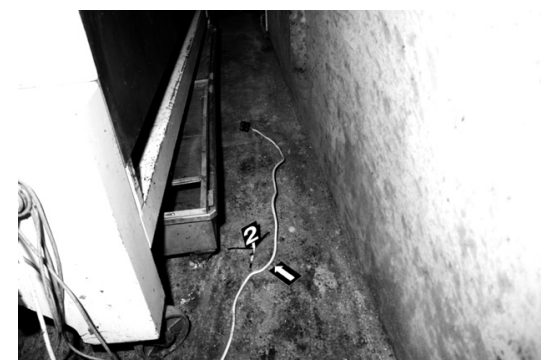

Slika 3. Položaj kabela od pumpe do mjesta priključka

Figure 3. Cable position from the pump to the plug

- Na kraju kabela nalazio se trofazni utikač (slika 4) koji je bio priključen na zidnu utičnicu (slika 5).

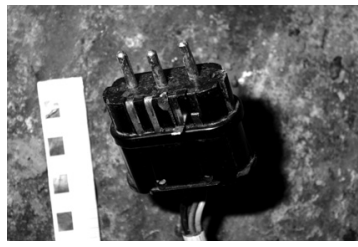

Slika 4. Trofazni utikač kabela

Figure 4. Three phase cable plug

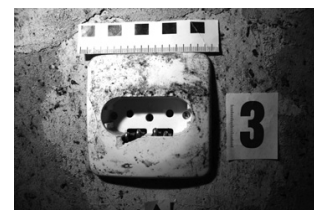

Slika 5. Trofazna zidna utičnica na koju je bio priključen kabel

Figure 5. Three phase wall socket where the cable was plugged in

\section{Pregled $\mathrm{i}$ ispitivanje materijala vještačenja}

Pregled i ispitivanje materijala vještačenja izvršen je u radionici za prometna i tehnička ispitivanja u Centru za forenzična ispitivanja, istraživanja i vještačenja "Ivan Vučetić" (CFIIV "Ivan Vučetić"); (Papić, 2009.).

Na vještačenje je dostavljeno sljedeće:

\begin{tabular}{|c|c|l||}
\hline \hline OMOT & 1 & $\begin{array}{l}\text { Električna pumpa, koja je izuze- } \\
\text { ta iz pomoćne zgrade obiteljske } \\
\text { kuće. }\end{array}$ \\
\hline
\end{tabular}

- Vizualnim pregledom pumpe dostavljene na vještačenje, omot 1 , utvrđeno je da na metalnom kućištu elektromotora i pumpe, te metalnoj konstrukciji kolica nema oštećenja (slika 6). Vizualnim pregledom kabela koji spaja priključnu kutiju elektromotora pumpe s upravljačkom kutijom, te pregledom razdjelnika i kabela koji se nalazi priključen u jednoj priključnici razdjelnika, ne nalaze se na istima tragovi mehaničkih i termičkih oštećenja.

- Vizualnim pregledom priključne kutije elektromotora pumpe i upravljačke kutije pumpe ne nalaze se na priključnim vodičima, priključnim kontaktima i kućištima uređaja tragovi mehaničkih i termičkih oštećenja.

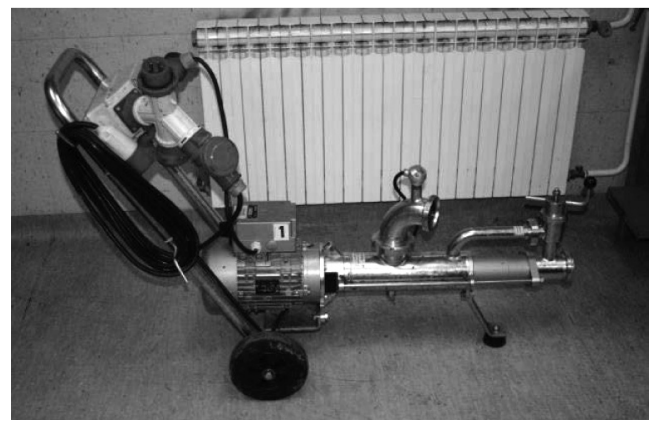

Slika 6. Pumpa za pretakanje mošta (omot 1)

Figure 6. Grape must pump

\begin{tabular}{|c|c|c||}
\hline \hline OMOT & 2 & $\begin{array}{c}\text { Trofazni produžni električni kabel, } \\
\text { koji je jednim krajem bio spojen } \\
\text { na pumpu, a drugi kraj kabela bio } \\
\text { je iskopčan iz utičnice i položen } \\
\text { na pod pored zida prostorije. }\end{array}$ \\
\hline
\end{tabular}


- Vizualnim pregledom trofaznog električnog kabela koji je na jednom kraju spojen preko kućanskog trofaznog utikača (slika 7) na istome se ne nalaze tragovi mehaničkih i termičkih oštećenja na izolaciji i plaštu kabela.

- Vizualnim pregledom kućanskog trofaznog utikača utvrđeno je da su dva kontakta na utikaču oštećena.

- Priključivanjem produžnog kabela na trofaznu priključnicu mjerno-ispitnog ormara oštećeni kontakti na trofaznom utikaču ne spajaju se s kontaktima u priključnici.

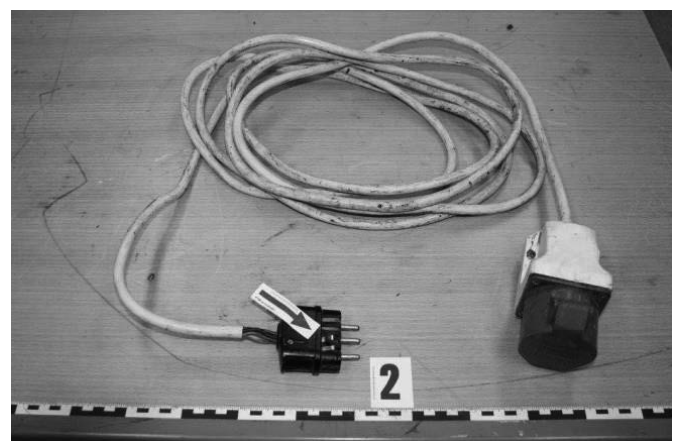

Slika 7. Produžni kabel (omot 2)

Figure 7. Extension cable

Ispitivanjem pumpe (omot 1) i produžnog kabela (omot 2) utvrđeno je sljedeće:

- Priključkom pumpe na mrežni napon pomoću produžnog kabela s oštećenim trofaznim utikačem, pomoću ispitivača napona utvrđeno je postojanje napona na ručki kolica i metalnim dijelovima kućišta pumpe. Mjerenjem napona između vodljivih metalnih dijelova pumpe (ručka kolica i kućište pumpe) i zaštitnog kontakta u najbližoj priključnici, izmjeren je napon od $70 \mathrm{~V}$ izmjenične struje (slika 8).

- Priključkom pumpe na mrežni napon nakon zamjene oštećenog utikača ispravnim trofaznim utikačem, pomoću ispitivača napona nije utvrđeno postojanje napona na ručki kolica i metalnim dijelovima kućišta pumpe.

- Mjerenjem otpora utvrđena je neprekinutost vodiča faza (3 vodiča), nultog vodiča i zaštitnog vodiča produžnog kabela.

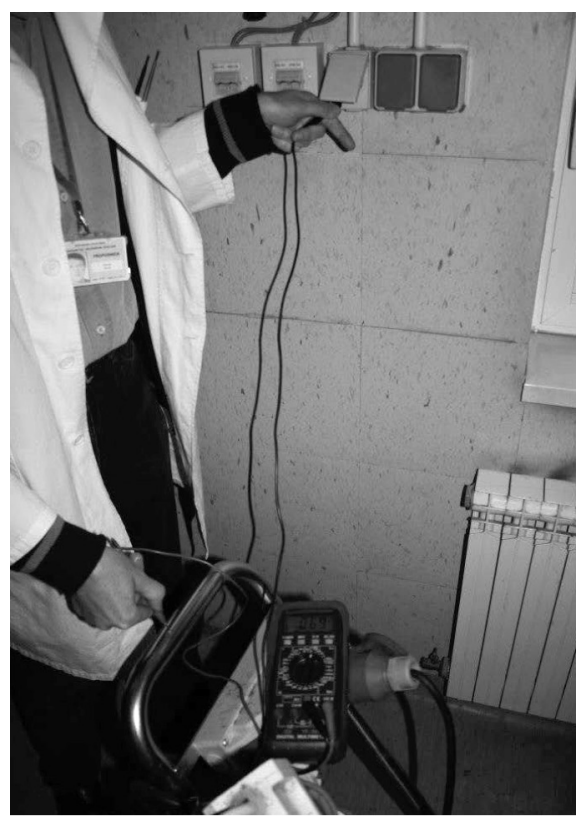

Slika 8. Ispitivanje pumpe

Figure 8. Pump testing

\section{Rezultati ispitivanja materijala vještačenja}

Na temelju pregleda materijala vještačenja i provedenih ispitivanja zaključeno je sljedeće:

- Vizualnim pregledom električne pumpe (omot 1) utvrđeno je da na metalnom kućištu, te na metalnoj konstrukciji kolica nema oštećenja. Pregledom upravljačke i priključne kutije pumpe, te kabela i razdjelnika koji se nalaze na pumpi, nije bilo tragova mehaničkih i termičkih oštećenja.

- Vizualnim pregledom produžnog električnog kabela (omot 2), na istom se ne nalaze tragovi mehaničkih i termičkih oštećenja na izolaciji i plaštu kabela. Pregledom trofaznog utikača produžnog kabela utvrđeno je da su dva kontakta na utikaču oštećena na način da se prilikom priključivanja na priključnicu isti ne spajaju s kontaktima u priključnici.

- Priključivanjem pumpe (omot 1) pomoću produžnog kabela (omot 2) na trofaznu priključnicu mjerno-ispitnog ormara na način da se zbog oštećenja zaštitni kontakti na utikaču produžnog kabela ne spajaju sa zaštitnim kontaktima na priključnici, na metalnim dijelovima kućišta pumpe utvrđeno je postojanje napona. 


\section{Zaključak o uzroku nesreće na temelju tehničkog vještačenja}

Nesreća se dogodila prilikom rada pumpe za pretakanje mošta na način da je u vlažnim uvjetima moglo doći do proboja napona na priključnom kabelu koji nije imao ispravno priključen vodič za uzemljenje, što je u slučaju dodira moglo dovesti do električnog udara (Papić, 2016. i 2017).

Vještak nije prisustvovao pregledu mjesta događaja, već je na vještačenje dobio pumpu i priključni kabel. Pregledom i ispitivanjem pumpe nije utvrđena neispravnost iste, ali je utvrđena neispravnost produžnog kabela kojim je pumpa bila priključena na električnu mrežu.

Mogući uzrok nesreće je korištenje neispravne električne instalacije, što se i dogodilo prilikom rada pumpe, gdje je korišten neispravan produžni kabel, odnosno pumpa je bila priključena kabelom s neispravnim utikačem na utičnicu bez odgovarajuće mehaničke zaštite za vlažne uvjete rada.

\section{VJEŠTAČENJE NA SUDU}

Opisano je vještačenje na sudskoj raspravi od vještaka za tehnička vještačenja i vještaka sudske medicine $u$ jednom predmetu smrtnog stradavanja od strujnog udara.

\section{Nalaz i mišljenje vještaka za tehnička vještačenja}

Samostalni vještak za tehnička vještačenja, diplomirani inženjer elektrotehnike, zaposlen u Centru za forenzična vještačenja "Ivan Vučetić" na sudu je usmeno dao svoj nalaz i mišljenje.

Zaključno je iznio sljedeće:

- Utvrđena neispravnost utikača produžnog kabela, priključivanjem pumpe preko istoga na električnu mrežu, u slučaju pojave opasnog dodirnog napona na električnom uređaju, doveo bi do toga da zaštita koja bi trebala reagirati u slučaju mogućeg kvara ne bi isključila električni uređaj na kojemu bi došlo do kvara.
- Priključak produžnog kabela na trofaznu utičnicu, zbog toga što su isti bili oštećeni, a nisu izvedeni u odgovarajućoj mehaničkoj zaštiti, moglo je u uvjetima mokre okoline na mjestu događaja dovesti u slučaju dodira do opasnosti od udara električne struje. U slučaju pojave dodirnog napona većeg od $50 \mathrm{~V}$, odnosno struje veće od 50 $\mathrm{mA}$, isto može biti smrtno opasno za čovjeka.

- Vještak za tehnička vještačenja nije imao primjedbi na sudsko-medicinsko vještačenje, odnosno složio se s nalazom i mišljenjem vještaka, a na temelju vlastitog iskustva složio se i s dijelom nalaza medicinskog vještaka u kojemu isti navodi da mogu, ali i ne moraju ostati tragovi termičkog djelovanja električne struje na mjestu dodira rukom ili drugim dijelom tijela.

\section{Nalaz i mišljenje sudsko-medicinskog vještaka}

Vještak sudske medicine, specijalist sudske medicine, zaposlen u bolnici na sudu je usmeno dao svoj nalaz i mišljenje:

- Nastradali je prema opisu događaja stradao, odnosno naglo umro, prilikom rada s pumpom za pretakanje mošta.

- Obdukcijom mrtvog tijela utvrđeni su sljedeći tragovi: oguljotina kože veličine $1,5 \times 0,3 \mathrm{~cm}$ na prstu lijeve šake i oguljotina veličine $1,8 \times 1,5$ na desnom laktu.

- Obdukcijom su utvrđene sljedeće patološke anatomske promjene: oteklina mozga, opća jaka zastojna punokrvnost, otok pluća, te krvarenje u velikom mišiću s desne strane vrata.

- Zaključak obducenta je da je nastradali umro od akutnog otkazivanja funkcije srca.

- Iskustvo istraživanja velikog broja događaja udara električne struje ukazuje da se konačni zaključak donosi na temelju cjelokupne analize okolnosti događaja, tehničkog vještačenja i medicinskog nalaza prilikom obdukcije smrtno nastradalog. 
- Ključne su sljedeće činjenice: što se događalo, gdje je nastradali konkretno radio, je li bio u dodiru s električnom strujom, da je utvrđena neka tehnička neispravnost (u konkretnom slučaju tehničkim vještačenjem utvrđeno je da produžni kabel nije bio ispravan) i da medicinski nalaz ukazuje na naglu i iznenadnu smrt.

- Istraživanja događaja strujnog udara ukazuju da se tzv. "električni biljezi“, odnosno termička oštećenja na koži, najčešće na rukama (prstima), ne moraju uvijek pronaći prilikom medicinske obrade umrle osobe.

- Električni biljezi su karakterističan trag da je osoba došla u dodir s električnom strujom, ali nisu apsolutan dokaz. To je termička ozljeda koja nastaje zbog jakog zagrijavanja ljudskog tkiva na mjestu dodira s električnom strujom. Kada se radi o kontaktu sa širokom površinom uređaja koji su pod naponom, tada je i manja mogućnost da se koncentrira toplina na jednom mjestu i manja je mogućnost da nastanu električni biljezi.

- Može se zaključiti da se udar električne struje može dogoditi i čovjek može smrtno stradati od udara struje, a da na tijelu nema biljega.

- Nalaz obdukcije u kojemu se navodi jaka punokrvnost svih organa i otok pluća i mozga ukazuje na naglo otkazivanje rada srca.

- Električna struja je fatalna za čovjeka zato što pogađa srce i prolaskom kroz srčani mišić uzrokuje poremećaj prirodnog ritmičnog stezanja i opuštanja srca. Prolazak struje kroz srce izaziva fibrilacije i aritmije, odnosno nepravilne ritmove rada srca zbog kojih ono više ne funkcionira i ne pokreće krvotok.

- Prema opisu događaja nastradali je naglo izgubio svijest i pao, a jedan od svjedoka je izjavio da su ga pokušali oživljavati, ali bez uspjeha. To je upravo zbog toga što je struja uzrokovala nepravilan rad srca (fibrilaciju) i vanjskom masažom nije se uspjelo pokrenuti srce u pravilan ritam.
- Obdukcijski nalaz ukazuje na nagli prestanak rada srca, zbog udara električne struje.

\section{ZAKLJUČAK}

Pregled i ispitivanje na mjestu događaja nesreće obavlja vještak za elektrotehnička vještačenja, kao i pregled i ispitivanje električnih uređaja za koje se sumnja da su svojom neispravnošću mogli uzrokovati električni udar. Pregled električne instalacije i električnih uređaja na mjestu događaja zbog utvrđivanja kvara ili neispravnosti na istima kao mogućeg uzroka strujnog udara izvodi se u beznaponskom stanju.

Pregled nastradalog i utvrđivanje ozljeda i uzroka stradavanja obavljaju liječnik, patolog ili vještak sudske medicine.

Vještačenje uzroka električnog udara je kombinirano vještačenje vještaka za elektrotehnička vještačenja i sudsko-medicinskog vještaka.

U radu je opisan jedan realan slučaj iz područja rada vještaka za elektrotehniku, te je prikazan postupak vještačenja dostavljenog materijala zbog utvrđivanja uzroka strujnog udara.

Navedeni slučaj bio je predmet rada vještaka medicinske struke te su navedeni učinci električne struje na ljudski organizam prilikom strujnog udara.

Na kraju je prikazano zajedničko vještačenje vještaka za tehnička vještačenja i vještaka sudske medicine na sudskoj raspravi.

\section{LITERATURA}

Dettmeyer, R. B., Verhoff, M. A., Schütz, H. F.: Electricity, Lighting and Gases, Forensic Medicine, Fundamentals and Perspectives, Springer Heidelberg, 2014., pages 213-226.

Keler, D., Maričević, M., Srb, V.: Elektromonterski priručnik, Tehnička knjiga, Zagreb, 1987.

Komen, V.: Sigurnost u primjeni električne energije, 2. Djelovanje električne struje na 
čovjeka, dosupno na: www.veleri.hr>SUPEE_ POG_02, pristupljeno: 1.12.2017.

Marcikić, M., Dumenčić, B., Matuzalem, E., Čačinović, V.: Electrocution, Three cases of high-voltage deaths, 16th Alps-Adria-Panonia Meeting on Forensic Medicine, Debrecen, 2007.

Mileusnić, E.: Mjere sigurnosti i zaštite na radu kod primjene električne energije, ZIRS, Zagreb, 1999.

Papić, N.: Zapisnik o vještačenju i fotografije sa očevida i vještačenja, CFIIV „Ivan Vučetić", 2009.
Papić, N.: "Elektrotehnička vještačenja", CFIIV "Ivan Vučetić", 2016., dostupno na: www. forenzika.hr/973.aspx, pristupljeno: 1. 12.2017.

Papić, N.: Nesreće uzrokovane strujnim udarom, 6. Međunarodni stručno-znanstveni skup "Zaštita na radu i zaštita zdravlja" u Zadru, Veleučilište u Karlovcu, zbornik radova, 2016., str. 969-974.

Papić, N.: Nesreće na radu uzrokovane udarom električne struje, Sigurnost, 3, 59, 2017., str. 245-253.

Srb, V.: Električne instalacije i niskonaponske mreže, Tehnička knjiga, Zagreb, 1991.

\section{EXPERT REPORTING ON ACCIDENTS CAUSED BY ELECTRIC SHOCK}

SUMMARY: The paper focuses on a real accident and on the report as to the causes leading to the electric shock, drafted by an expert in electrical engineering. Described are the circumstances surrounding the accident and the methods of treatment of the materials found on the accident site. In addition, safety measures are outlined that need to be observed on sites where an accident involving electric shock can occur.

The authors provide data on the impacts of electricity on human organism in the event of electric shock, which is the field of court medical experts.

Expert reporting on the cause of electric shock requires an expert in electrical engineering and a medical expert. One such court hearing is presented in the paper.

Key words: accidents, electric shock, electric engineering expertise, medical expertise, court hearing

Professional paper

Received: 2017-12-28

Accepted: 2018-03-21 